\title{
多段表面処理シリカ粒子添加によるポリカーボネート 複合系の熱安定効果と衝撃強度の向上
}

\author{
日下石 進*1 菅野真 紀*1 $\cdot$ 中島信 哉*2
}

\section{The Effects of Addition of Multistage Surface-treated Silica Particles in Polycarbonate Composites}

\begin{abstract}
Nikkeshi, Susumu*1/Kanno, Maki*1/Nakajima, Shinya*2
The thermal stability and recyclability of polycarbonate resin (PC) composites filled with silica particles which are surface-treated with polyhydric phenol agents has been investigated. The composites were evaluated after molding 4 consecutive times. For the composites containing 1.5 wt\% silica particles treated with polyhydric phenol, the number-average molecular weight $\left(M_{n}\right)$ of $\mathrm{PC}$ in the composites, measured by gel permeation chromatography, decreased from 24300 to 21800 after 4 injection molding cycles, while the unfilled PC resin control decreased to 21000 .

These results suggest that the PC molecule depolymerized during the injection molding process due to the thermal energy and stress. On the other hand, we found that the surface treatment of silica particles with polyhydric phenol reduced the decrease in PC Izod impact strength to $1 / 5$ that of the neat PC resin. In addition, we studied the effects of multistage surface treatment of silica particles using two phases and three phases with benzophenone, silane-coupling agents. Three phase multistage treated silica particles resulted in higher $M_{n}$ retention than those containing a single phase with polyhydric phenol.

The magnitude of the activation energies $(\Delta E)$ related to the thermal degradation of the composites were evaluated by thermo-gravimetry. $\Delta E$ increased in the following order: neat PC, composite with the two-phase multistage and that with the three-phase multistage.

These findings suggest that the addition of multistage surface-treated particles in PC improved the stability of PC composites. This implies that surface treatment may be an effective method in the recycle of $\mathrm{PC}$ resin composites.
\end{abstract}

Key words : Silica particle/Multistage surface treatment/Activation energy/Recycles/

Polycarbonate resin

\section{1. 緒言}

ポリカーボネート (PC) は射出成形などの成形工程に おいて，加熱やせん断応力などの影響により熱分解，加水 分解(1) などを起し，分子量が低下することが知られてい $る^{5), 6)}$. このため, PC の機械的特性の低下を招いて成形品 の欠陥を増加させ，さらには射出成形時に発生するスプ

*1 東北ムネカ夕(株) 機能樹脂部

福島市蓬莱町 1-11-1（T960-8506）

Intelligent Material Dept., Tohoku Munekata Co. Ltd.,

1-11-1, Horai-Cho, Fukushima-City, 960-8506, Japan

*2 (侏龍森 開発研究情報部

東京都港区芝公園 2-9-3（开105-0011）

Research and Development Division, Tathumori Ltd., Shiba-Lawyer Bldg., 2-9-3,Shibakoen Minato-ku, Tokyo, 105-0011, Japan

1999.4.26 受理
ルーやランナーのリサイクルも困難となっている．これら は結果として資源消費や環境負荷の増加につながるため, 早急に対応する必要がある. 前報わにおいて, 多価フェノー ルによる表面処理シリカ粒子の添加によって PC の熱分解 をある程度抑制できることを報告したが, この中で, IZOD 衝撃強度が低下することが課題であった。本報ではこれを 解決するため, シリカ粒子を多段に表面処理し，これを添 加することによって PCの射出成形時における分子量と IZOD 衝撃強度双方の低下を抑制することを目的とした. ここでは，PCのリサイクル性を考慮するため, 実際の射 出成形機を用いて射出成形を繰り返し行い, 各種多段表面 処理シリカ粒子を PC に添加した系について分子量変化と 衝撃強度変化から評価した。また, 熱分解に関する活性化 エネルギーを求め, 熱安定性を確認した。 


\section{2. 実験}

\section{1 試料}

$\mathrm{PC}$ 樹脂は前報》 と同じ帝人化成(侏製パンライト L 1250 ペレット（分子量 $M_{n}=24300, M_{w}=58000, M_{w} / M_{n}=$ 2.39）を用い，シリカ粉末はUnimin Speciality Minerals Inc. 製 IMSIL A-25（粘径 $3.5 \mu \mathrm{m}$ ，密度 $2.65 \mathrm{~g} / \mathrm{cm}^{3}$ ) を 真空デシケーター中で $24 \mathrm{hr}$ 以上乾燥して使用した。 シリ カ粉末の表面処理剤として, 多価フェノール (小宗化学(株), 試薬 1 級, 以下 $\mathrm{CT}$ と記す) と, ベンゾフェノン（和光純 薬工業(侏製，試薬 1 級，以下 $\mathrm{BP}$ と記す)，およびシラン 系カップリング剂である $\gamma$-Methacryloxypropyl trimethoxysilane（信越化学工業(侏製，KBM 503，以下 SC と記す) を用いた。な押，表面処理剤の各化学構造式 ${ }^{8) ~ 10) ~ F i g . ~} 1$ に示した。

\section{2 多価フェノールによるシリカ粒子表面改質法}

前報》よりやや規模を大きくした以外は，全く同様の装 置, 条件で $5000 \mathrm{~m} \ell$ のポリプロピレン樹脂製容器にシリ 力粒子を $1.5 \mathrm{~kg}$ 計量し, 分散媒として純水 $2000 \mathrm{~g}$, さら にシリカ粒子に対し $2 \mathrm{wt} \%$ の C を加え，前報》と同じ攪 汼機（姝井内盛堂製，ラボミキサーS 型）を用いて $45 \mathrm{~min}$ 間摚拌した。このとき，攪找羽根は $\mathrm{M}$ 型プロペラ（直径 $60 \mathrm{~mm}$ ) とし, 回転速度は概ね 120 150 rpm であった。 その後, 純水で洗浄しながら吸引ろ過し， $40^{\circ} \mathrm{C}, 24 \mathrm{hr}$ 真 空乾燥を行い，その後デシケーター中に保存した。ここで, 表面処理シリカ粒子に付着している多価フェノールの量は, 前報》と同样に熱重量分析に扔ける酸素気流中 $800^{\circ} \mathrm{C}$ の減 量値と, 水分の乾燥減量の值から求めたところ, $0.986 \mathrm{wt}$ \%であった。

\section{3 多段表面処理法}

調整した多価フェノール処理シリカ粒子 $500 \mathrm{~g}$ を用い, ベンゾフェノンを 2 段目の表面処理剛とし，分散媒に純水

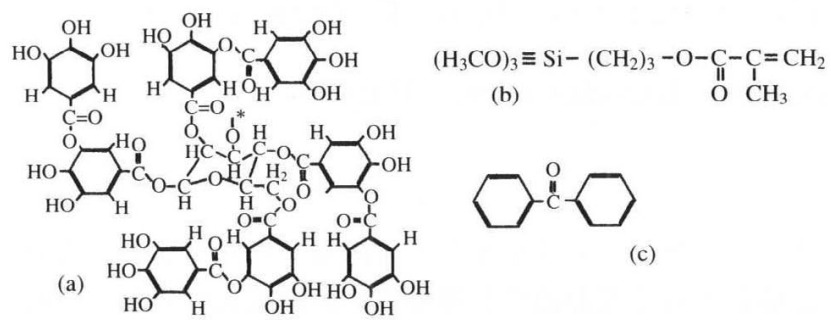

Fig. 1 Chemical structure of the surface-treatment reagents in this study. (a) : polyhydric phenol (The $*$ mark indicates the position where gallic acid dimmer group locates) ; (b) : silan coupling agent ; (c) : benzophenon

Table 1 Condition of the injection molding

\begin{tabular}{l|r}
\hline \multicolumn{1}{c|}{ Condition } & Values \\
\hline Nozzle temperature $\left({ }^{\circ} \mathrm{C}\right)$ & 286 \\
\hline Injection pressure $\left(\mathrm{kgf} / \mathrm{cm}^{2}\right)$ & 995 \\
\hline Holding pressure $\left(\mathrm{kgf} / \mathrm{cm}^{2}\right)$ & 595 \\
\hline Injection time $(\mathrm{sec})$ & 1.61 \\
\hline Holding time $(\mathrm{sec})$ & 21.4 \\
\hline Cooling time $(\mathrm{sec})$ & 45.0 \\
\hline
\end{tabular}

の代りにキシレン（関東化学侏製，試薬 1 級）を用いた以 外は前項の多価フェノール処理と同様にしてシリカ粒子に 対し 2 段目の表面処理を行った。さらに, ベンゾフェノン 処理終了後のシリカ粒子に対して，同様にカップリング剤 処理を行い，シリカ粒子に対して 3 段目の表面处理を行っ た.

\section{$2.4 \mathrm{PC}$ 複合系試料の成形とリサイクルおよび破断面 の SEM 観察}

PC 複合系試料は射出成形機（東芝機械侏製 IS- 170 F 型, 型締め圧力 170 ton）を用い，Table 1 に示す成形条件で成 形した。用いた金型は，各種試験片 ${ }^{111}$ が共取り可能で, Fig. 2 に示した. IZOD 衝撃試験片は JIS K 7110, 引張り 強度試験片はJIS K 7113，曲げ強度試験片はJIS K 7203 に準拠しており，さらに $2.5 \mathrm{~mm} \times 127 \mathrm{~mm} \times 254 \mathrm{~mm}$ の平 板が同時に成形できる金型を用いて成形した．PC 材料の 100\%のリサイクルを試み，PC を 1 回成形するごとに試 験片 5 セットを取り出し, 成形した残りの試験片をすべて 粉砕機（日水化工侏製 FNSK-15 D $1.5 \mathrm{~kW}$ ）を用いて粉 砕した。粉砕された樹脂は再度, 除湿乾燥機（侏)カワタ製 DR-30 Z 型)，押よび温調機（侏加藤理器製作所製 DN 220-3 型）を用いて $110^{\circ} \mathrm{C}, 4 \mathrm{hr}$ 乾燥し，同条件で射出成形 を繰返した。このとき，成形した回数を試料の末尾に付け， ロット番号とした。例えば何も添加していない PCペレッ 卜を用いて射出成形して得た試験片を B 1 とし，2 回目の 成形品を B 2 とし成形回数を末尾に付けた。また，各種表 面処理シリカ粒子を加えた PC の場合も同様にして Table 2 に示した。

また，IZOD 衝撃によって破断した断面を観察するため， 一部の IZOD 衝撃強度測定後の試験片を用い，イオンコー 夕ー（日本電子(侏製，JFC-1100 E) で $10 \mathrm{~mA} ， 150$ 秒の 条件で Au コーティング処理を行った。これを SEM（日 本電子(侏製，JSM-5300 型）で，加速電圧 $25 \mathrm{kV}$ で観察を 行った.

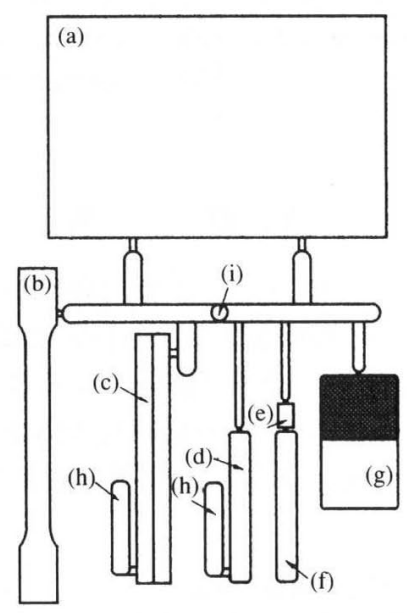

Fig. 2 Specimens set of mechanical properties test by injection molding. (a) : falling impact plate ; (b) : tensile strength bar ; (c) : HDT test stick ; (d) : IZOD impact test stick ; (e) : compression test tip ; (f) : fulexal test stick ; $(\mathrm{g})$ : plate of colors test plate ; (h) : dummy pocket ; (i) : sprue 
Table 2 List of used materials

\begin{tabular}{|c|c|c|c|c|c|}
\hline \multirow[b]{2}{*}{ Lot No. } & \multirow[b]{2}{*}{ Particle } & \multicolumn{3}{|c|}{ Treatment agent $(\mathrm{wt} \%)^{*} 1$} & \multirow{2}{*}{$\begin{array}{l}\text { Added } \\
\text { in PC } \\
(\operatorname{vol} \%)\end{array}$} \\
\hline & & $\begin{array}{l}\text { Poly- } \\
\text { phenol }\end{array}$ & $\begin{array}{l}\text { Benzo- } \\
\text { phenon }\end{array}$ & $\begin{array}{c}\text { Coupling } \\
\text { agent }\end{array}$ & \\
\hline B 0 & - & - & - & - & - \\
\hline BS & Sillica & - & - & - & 1.5 \\
\hline ST & Sillica & 2.0 & - & - & 1.5 \\
\hline STB & Sillica & 2.0 & 2.0 & - & 1.5 \\
\hline STS & Sillica & 2.0 & 一 & 2.0 & 1.5 \\
\hline STBS & Sillica & 2.0 & 2.0 & 2.0 & 1.5 \\
\hline
\end{tabular}

$* 1$ : Concentration of treatment agent as against filler

\subsection{IZOD 衝撃強度と MFR の測定}

IZOD 衝撃強度は JIS K 7110 に従い, 測定装置は, 東洋 精機製作所(侏)製，JISL-D 型を用いた．試験片への V Vッ 于加工は同社製 B-3515 型を用いた．以上の衝撃強度測定 環境は JIS Z 8703 に準拠して試験片を温度 $23^{\circ} \mathrm{C}$, 湿度 50 $\sim 60 \mathrm{RH} \%$ 環境に $24 \mathrm{hr}$ 以上放置後，測定した。メルト フローレート（MFR）は PC の流動性変化が分子量変化 の傾向を表すのに好都合である ${ }^{12}$ ため, 分子量測定結果の 毫付けとして JIS K 7210 に従い，東洋精機製作所侏製， メルトインデクサー C-50 型を用い温度 $280^{\circ} \mathrm{C}$ ，荷重 2.16 $\mathrm{kg}$ の条件にて測定した.

\section{$2.6 \mathrm{PC}$ 平均分子量の測定}

$\mathrm{PC}$ の平均分子量は, 前報》と同じ装置である日立製作 所侏製 GPC L-7000 型を用い，同条件下で試料を処理し測 定を行った. 平均分子量は, あらかじめ標準ポリスチレン (PRESSURE CHEMICAL Co. 製 Standard PS, $M_{w} / M_{n}$ =1.06） を THF 溶媒に試料と同濃度で溶解し，分子量と カラム排出時間の検量線から相対的に換算して求めた.

\subsection{TG-DTA の測定}

小沢-Doyle 法 ${ }^{13), 14}$ による熱分解に関する活性化エネル ギー $(\Delta E)$ を求めるために，真空理工侏製示差熱分析装 置 TGD 9000 型を用いて, $30^{\circ} \mathrm{C} \sim 560^{\circ} \mathrm{C}$ の温度範囲で熱重 量変化の測定を行った，このとき，雲囲気は $\mathrm{N}_{2}$ ガスを 100 $\mathrm{m} \ell / \mathrm{min}$ で流し, 昇温速度を $10,20,40,75^{\circ} \mathrm{C} / \mathrm{min}$ と変 化させ，試料リファレンスとして $\alpha-\mathrm{Al}_{2} \mathrm{O}_{3}$ を用いアルミニ ウムセルにて測定した。

\section{3. 結果および考察}

\section{1 表面処理シリカ粒子/ PC 複合系における $\mathrm{PC}$ 分子 量と IZOD 衝撃強度の変化}

Fig. 3 に各複合系を射出成形し，これを繰返したときの $\mathrm{PC}$ 分子量 $\left(M_{n}\right)$ 変化を示した。いずれの複合系において も $M_{n}$ は射出成形の絽返し回数の増加とともに低下した。 B 0 と BS はほほ同様な傾向で低下し, 混練前は 24300 で あったが, 4 回の成形後には 21000 程度となった，B 0 に 較べ, BSは，やや $M_{n}$ の低下が大きい。これは，シリカ 粒子は PC の混練時に溶融しないため, シリカ粒子の添加 によって PC 分子へのせん断応力が大きくなり, メカノケ ミカル効果によって $M_{n}$ が低下したと考えられる.

一方，多価フェノール表面処理シリカ粒子を加えたST は $M_{n}$ 低下量は小さく, 前報》で報告したとおり, 多価フェ ノールによる熱安定効果が得られている.

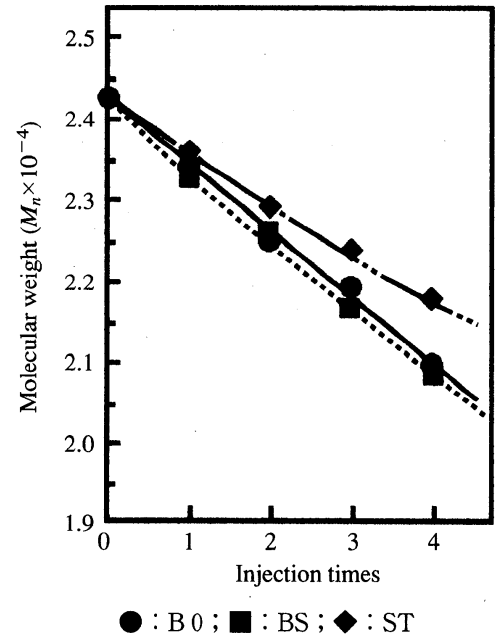

Fig. 3 Changes in PC molecular weight as a function of injection times

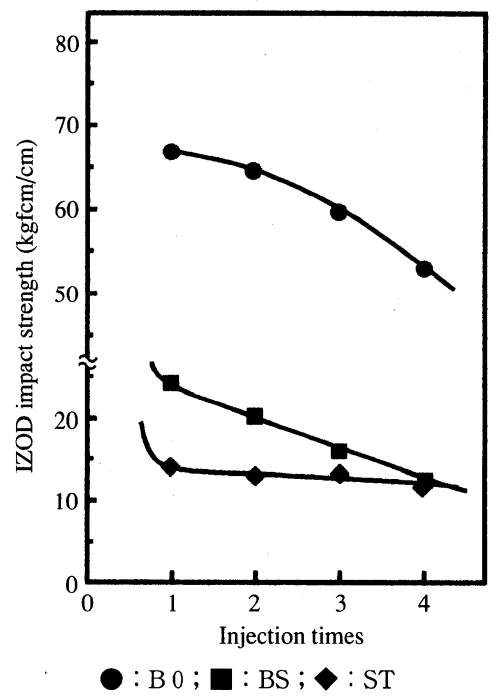

Fig. 4 Injection times dependence of IZOD impact strength for various composites

Fig. 4 に同じ試料の IZOD 衝撃強度をそれぞれ示した. 表面処理の有無にかかわらずシリカ粒子の添加は, IZOD 衝撃強度を大きく低下させる。これは剛性の大きな粒子を 添加することにより，Vノッチの谷に集中する応力に対し PC マトリックスの分子鎖セグメント運動性が低下して, 脆性破壊に至る ${ }^{15), 16)}$ ためと考えられる。また IZOD 衝撃強 度は，BSより STのほうがさらに低下している。これは シリカ粒子表面に較べ多価フェノールは, 親水性が極めて 大きく, PCマトリックスと粒子界面においては多価フェ ノール処理シリカ粒子のほうが PC との濡れ性が小さい. このため, 多価フェノール処理シリカ粒子と PCマトリッ クス間にほとんど相互結合は生じない。 その結果, PC マ トリックスとシリカ粒子は熱膨張率や硬度および剛性など の異なるこの界面に微少な空隙を生じることになる。こう

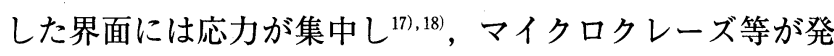
生することにより，IZOD 衝撃強度が低下した ${ }^{199}$ と考えら れる。したがって， $M_{n}$ の低下を抑制しつつ，IZOD 衝撃 強度の低下も抑えるためには, 多価フェノールの熱安定効 果を保持しながら，一方で高剛性の充填材とマトリックス 
高分子との界面に化学的な結合が存在することが望まれる.

3.2 シリカ粒子表面の多段表面処理が PC 分子量と IZOD 衝撃強度に及ぼす影響

Fig. 5 にB 0 および ST と 2 段表面処理シリカ粒子/PC 系の STB と STS, および 3 段表面处理シリカ粒子/PC 系 のSTBSについて, $M_{n}$ の変化を示した．射出成形回数の 増加とともにすべての系で $M_{n}$ は低下している. STBは ほとんど ST と差異はなく, 多価フェノールのPC 熟妿定 効果の特性は失っていない. またさらに, STS と STBS は, ST 系よりも，己らに熱安定性に優れた結果となった。 これは, 多価フェノール層がベンゾフェノンやカップリン グ剂により打打われることで，射出成形プロセス温度であ る $290^{\circ} \sim 310^{\circ} \mathrm{C}$ 近傍まで多価つェノールが保護され, その

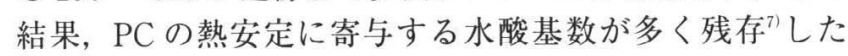
ためと考えられる.

これをさらに裏づけるため, 各複合系について MFR 求めFig. 6 に示した。ブランクと比較すると, 多段表面処 理シリカ粒子の添加が PC の溶融粘度上昇を顕著に抑えて おり，前述の Fig. 5 に示した $M_{n}$ の結果を反映している.

Fig. 7 に多段表面処理シリカ粒子分散系の IZOD 衝撃強

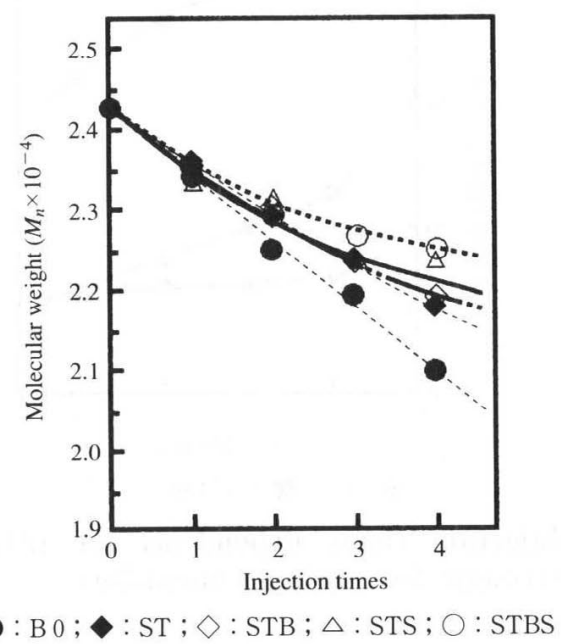

Fig. 5 Changes in PC molecular weight as a function of injection times

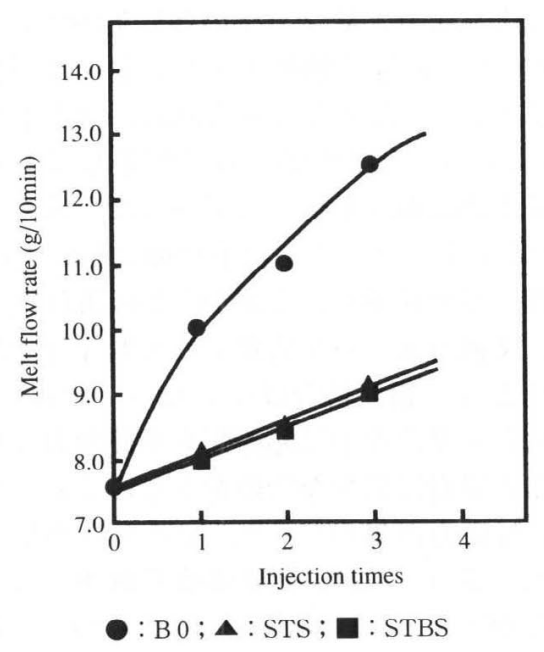

Fig. 6 Injection time dependence of melt flow rate for various samples
度を示した，成形回数の増加に従い, IZOD 衝撃強度も低 下しているが，これは $M_{n}$ の低下に伴って現れる200であ ろう。したがって, $M_{n}$ の低下率が小さかったSTS や STBS のほうが, PCブランクより, IZOD 衝撃強度が大きい結 果となった。ささらに, これらの複合系の IZOD 衝撃強度は, PC ブランクの初期値より大きくなっている. これは, シ リカ粒子表面が多段处理されたため, 表面層が比較的厚く なり，応力を吸収したと考えられる。即ち，シリカ粒子は 高㴊性であるが，粒子表面に多価フェノールやフェノン化 合物, シランカップリング剂等が積層状態となっているこ とが, 表面処理手法から考えられる. シリカ粒子表面にこ うした層が存在することにより，ゴム弾性粒子の分散複合 系と類似した挙動を示したと推測される．L. E. Nielsen ${ }^{21}$ はポリスチレンへのゴム粒子分散系を例として、ゴム層と スチレン層との付着が良好であれば, 衝撃強度は向上する ことを述べて抢り，シリカ粒子が多段表面処理されたこと によって, PC との需れ性が向上するとともに，その内側 層がベンゾフェノン層と多価フェノール層が存在するため, ABS や HI-PS の中に分散するブタジェン粒子と類似した 状態と推測される.

\section{3 破断面の観察と粒子の分散性}

Fig. 8 にIZOD 衝撃強度測定後の破断面 SEM 観察結果

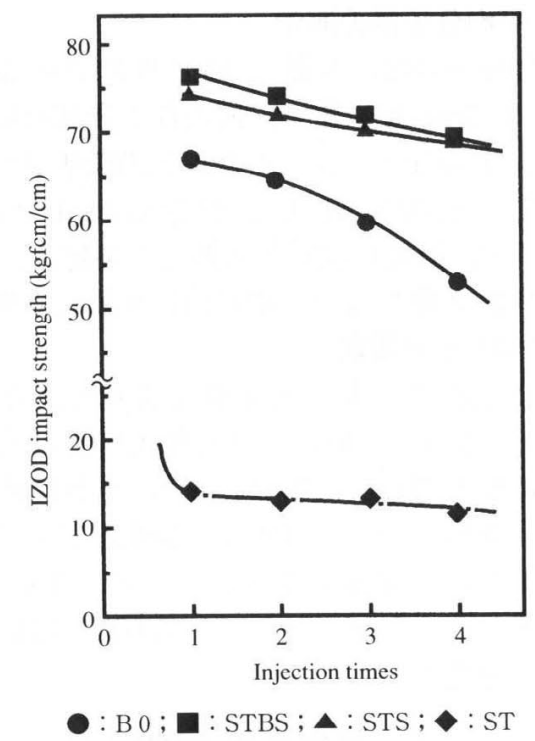

Fig. 7 Injection times dependence of IZOD impact strength as a various samples

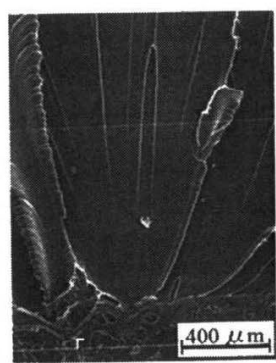

(a)

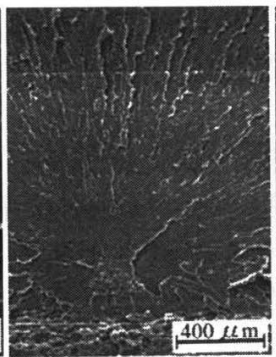

(b)

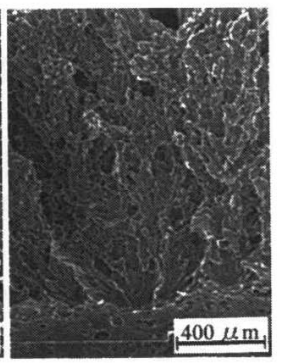

(c) (a) : PC blank specimen ; (b) : BS ; (c) : STBS

Fig. 8 SEM photographs for the fracture surface of PC composites 
をB０を(a)に，STを(b)に，STBSを(c)にそれぞれ示し た. B 0 は写真下部の V ノッチ側から上方へ応力が伝播し, ガラス状の脆性破断面と延性破断面の両方 ${ }^{22}$ が観察される. したがって, GP ポリスチレン等の脆性のみの破断面23) と は異なり，衝撃応力がある程度延性破壊によって吸収され ていることが現れて扔り，PCの衝撃強度の大きいことと 一致する.ST は高㴊性の複合材料によく現れる破断形状 面 ${ }^{24)}$ を示しており，IZOD 衝撃強度の低下を裏付ける結果 となっている.さらにSTBSは延性破壞時の表面状態が 観察され, Fig.7の IZOD 衝撃強度の値と一致する.

Fig. 9 に, シリカ粒子分散状態の SEM 観察結果を, BS を(a)に，STを(b)に，STBSを(c)にそれぞれ示した. BS およびST 中のシリカ粒子は, 二次凝集体として観察され, 分散不良が観察される. BSの場合には未处理であること から，表而は自然に形成された水酸基等が多くあり，PC との濡れ性が良くないためと考えられる。また，STの場 合は，多価フェノール处理シリカ粒子であることから，シ リカ表面は，BSよりさらに多くの水酸基で扔抒われてい るため, PCマトリックスとの濡れ性は良くないと考えら れる。こうしたことが，Fig.7の衝撃強度や破断面状態に 反映していると推測される。一方, STBSは二次凝集が皆 無ではないが, 分散性の向上が観察されている.これは, カップリング剤処理によって，PCマトリックスと表面処 理シリカ粒子の親和性が向上したためと考えられ，前述し たように, IZOD 衝撃強度や破断面観察結果と一致する。

\section{4 熱分解活性化エネルギーによる表面処理シリカ粒 子 PC 複合系の評価}

多段表面処理シリカ粒子の添加による PC の熱安定効果

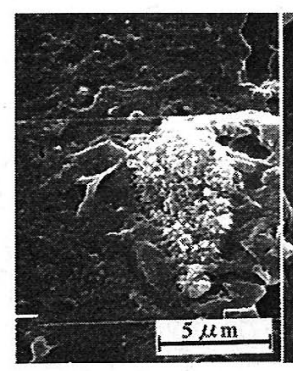

(a)

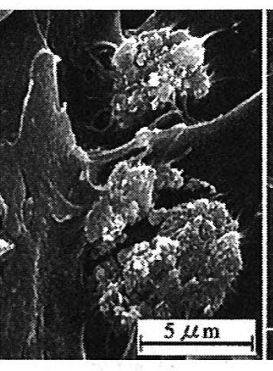

(b)

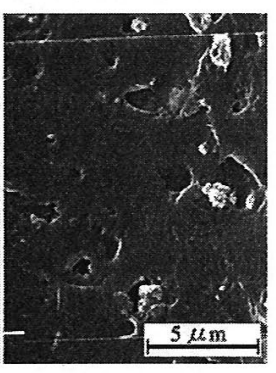

(c) (a) : BS ; (b) : ST ; (c) : STBS

Fig. 9 SEM photographs for the fracture surface of PC filled with silica particles

Table 3 Values of degradation temperature as a temperature programmed speed

\begin{tabular}{cc|c|c|c|c}
\hline \multirow{2}{*}{ Sample } & & \multicolumn{4}{|c}{ Temperature-programed speed $\left({ }^{\circ} \mathrm{C} / \mathrm{min}\right)$} \\
& & 10 & 20 & 40 & 75 \\
\hline \multirow{2}{*}{ B 0 } & $T_{d}\left({ }^{\circ} \mathrm{K}\right)$ & 720.5 & 739.7 & 757.6 & 775.9 \\
& $\left(1 / T_{d}\right) \times 10^{3}$ & 1.388 & 1.352 & 1.320 & 1.290 \\
\hline \multirow{2}{*}{ B 4 } & $T_{d}\left({ }^{\circ} \mathrm{K}\right)$ & 734.5 & 752.4 & 774.4 & 785.8 \\
& $\left(1 / T_{d}\right) \times 10^{3}$ & 1.361 & 1.329 & 1.291 & 1.272 \\
\hline \multirow{2}{*}{ STBS 4 } & $T_{d}\left({ }^{\circ} \mathrm{K}\right)$ & 739.8 & 756.4 & 775.6 & 788.2 \\
& $\left(1 / T_{d}\right) \times 10^{3}$ & 1.352 & 1.322 & 1.289 & 1.269 \\
\hline \multirow{2}{*}{ SIS 4 } & $T_{d}\left({ }^{\circ} \mathrm{K}\right)$ & 733.7 & 751.1 & 776.5 & 784.4 \\
& $\left(1 / T_{d}\right) \times 10^{3}$ & 1.363 & 1.331 & 1.288 & 1.275 \\
\hline \multicolumn{4}{|r|}{}
\end{tabular}

をさらに詳しく検討するため, 熱分解に関する活性化エネ ルギー $(\Delta E)$ を求めた。この $\Delta E$ を求める計算式は様々 に提案されている ${ }^{25), 26}$ が，ここでは反応機構が不明確で あっても適用可能とされる小沢-Doyle 法 ${ }^{13), 14}$ を用いて， 近似的に $\Delta E$ を求めることを試みた。

いま, PCが分解し, 気体が発生する不均一系分解反 応 ${ }^{27), 28)}$ を考えると，反応速度は，

$$
\frac{\mathrm{d} x}{\mathrm{~d} t}=K(1-x)^{n}
$$

ここで, $K$ は反応速度定数， $x$ は反応生成物の量, $n$ は反 応次数である. $K$ が Arrhenius 型で表される場合には次 式が成り立つ。

$$
K=A e^{-\triangle E / R T}
$$

(2) 式に抢いて, $A$ は頻度因子, $\Delta E$ は活性化エネルギー, $R$ は気体定数, $T$ は絶対温度である.この(2)式を変形し, さらに Doyleによって導入された関数韋を考慮することに より,以下の(3)式より $\Delta E$ を求めた。

$$
\Delta E=18.205 \frac{\log \beta_{2}-\log \beta_{1}}{\left(1 / T_{1}-1 / T_{2}\right)}
$$

熱分解反応時の昇温速度 $(\beta)$ の対数と分解温度を Arrhenius プロットしたときに直線群が得られるならば，こ れらの傾きから $\Delta E$ が求められる.

各複合試料の場合, 昇温速度を変化させて得られた熱分 解開始温度 $\left(T_{d}\right)$ は Table 3 のようになった。この $T_{d}$ の 絶对温度逆数と昇温速度の対数をプロットしたところ， Fig.10のように直線を得たので，この傾きから $\Delta E$ を得 た。この值を Table 4 に示した.この場合，B 0 と B 4 は 同じ值であった。一方, Table 3 や Fig. 10 に示されるよ うに, $T_{d}$ は B 00ほうが低い。一般に, 分子量が小さい ほうが(2)式で示される分解反応に関わる頻度因子は大き くなるため，相対的に $\Delta E$ は小さくなる．これが $T_{d}$ の低 下に現れており，同じ成形温度であれば， $\Delta E$ が同じで あっても B 0 より B 4 が熱分解しやすい傾向にある. $\Delta E$ が同じ值を示したのは，双方とも無添加の状態であり，熱 分解反応を阻害する物質もなく反応機構が同じであること ら Fig.10の傾きが等しくなったためと考えられる.

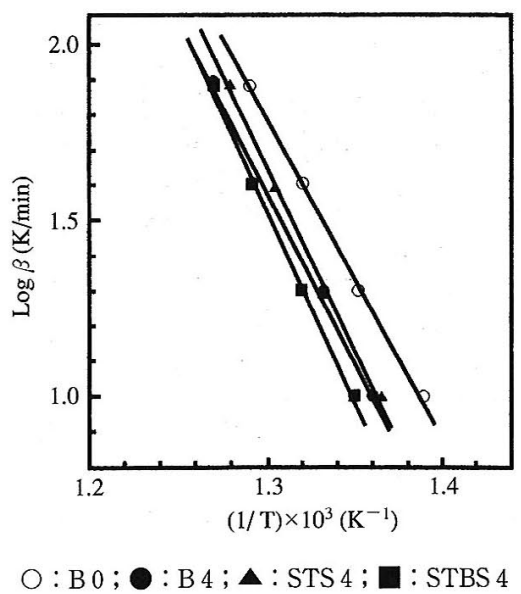

Fig. 10 The logarithmic plot of heating rate as a function of reciprocal absolute temperature of degradation 
Table 4 Activation energy of various samples

\begin{tabular}{l|c}
\hline Sample & Activation energy $(\mathrm{kJ} / \mathrm{mol})$ \\
\hline B 0 & 168.6 \\
\hline B 4 & 168.6 \\
\hline STBS 4 & 201.0 \\
\hline SIS 4 & 190.6 \\
\hline
\end{tabular}

3 段表面処理をしたSTBS 4 は最も $\Delta E$ の值が高かった。 これは PC の熱安定として働くCT が BP と SCによって 覆われ, PC の分解開始温度付近まで分解しにくい状態が 保たれたと考えられ，前述した $M_{n}$ や MFR の結果と一致 する.さらに，二段表面処理をしたSTS 4 は B 0，B 4 と STBS 4 の中間値となった。これは，2層処理をしたこと で一段目と二段目の中間的安定性となったのであろう. 以 上のことから，PCに多段表面処理シリカ粒子の添加によ り，PCの $\Delta E$ は向上することがわかった。このことから も，多段表面処理シリカ粒子の添加は，PCの熱安定に対 し効果的と考えられる.

\section{4. 結言}

実際の射出成形機で，PCを繰り返し成形した。この場 合, PCに多価フェノール表面処理シリカ粒子を数\%添 加・分散すると, 熱やせん断応力による PC 分子量低下を 抑制できるが, IZOD 衝撃強度は低下することがわかった。 この多価フェノールで表面処理したシリカ粒子を, カップ リング凨を用いて二段表面処理し，PCに分散した場合に は，PC の分子量低下は抑制され，かつ IZOD 衝撃強度も 向上した。また，この多価フェノールとカップリング剤の 中間層にベンゾフェノンを入れ三段表面処理とすれば, PC 分子量低下抑制効果をさらに大きくし, IZOD 衝撃強 度も同時に大きくなることがわかった。これらのことから， 物性の長期安定性などの確認が必要なものの, 多段表面処 理したシリカ粒子の添加は PCのリサイクルに対して効果 的な手段の一つと考えられる.

\section{付 記}

本研究の一部は, 第 10 回プラスチック成形加工学会年 次大会（1999 年 6 月, 東京）で発表した.

\section{参 考文 献}

1) Abbas, K. B. : Polymer, 21, 936 (1980)

2 ) Foti, S., Giuffrida, M., Maravigna, P. and Montaudo, G. : J. Polym. Sci., 21, 1567 (1983)

3 ) Lin, M., Bulkin, B. and Pearce, E. : J. Polym. Sci., 19, 2773 (1981)
4 ) Montaudo, G. : Polym. Degrad. Stabil., 26, 285 (1985)

5 ）松金幹夫, 田原省吾, 加藤修士：プラスチック材料講 座 5 「ポリカーボネート樹脂」, p. 144(1964), 日刊工 業新聞社

6 ）立川利久, 坂尻昭一：プラスチック材料講座 17 ,「ポ リカーボネート」p.83（1960），日刊工業新聞社

7 ）日下石 進, 石山英行, 工藤益男, 増子 徹 : 成形加 工, 11，891（1998）

8 ) Shor, J. : J. Soc. Dyers Colourists, 87, 3 (1971)

9 ) Nacalai Tesque General Catalog : 23, p.231 (1994)

10）材料技術研究協会 (編)：表面改質技術総覧, p. 356 (1993)，産業技術サービスセンター

11）日本規格協会 (編)：JIS ハンドブック「プラスチック」 p.177（1993），日本規格協会

12) Fox, T. J. and Flory, P. J. : J. Polym. Sci., 14, 315(1954)

13) Ozawa, T.: J. Thermal Anal., 2, 301 (1970)

14) Doyl, C. D. : J. Appl. Polym. Sci., 5, 285 (1961)

15）成澤郁夫：プラスチックの耐衝撃性, p. 100 (1994), シグマ出版

16）精機学会(編)：プラスチック複合材料, p.79 (1984), 日刊工業新聞社

17）石川 優：高分子論文集，47，83（1990）

18）根本紀夫，高原淳一：高分子サイエンス One Point-6 「高分子の力学物性」p.74（1996）, 共立出版

19）石川 優：高分子, 47, 326（1998）

20）五十野善信, 塩見友雄, 手塚育志: 高分子サイエンス One Point -1 高分子の分子量」p. 15（1992）, 共立 出版

21）Nielsen, E. L. (著), 小野木重治(訳)：高分子と複合材 料の力学的性質, p. 194 (1994), 化学同人

22）成澤郁夫：プラスチックの耐衝撃性, p. 43（1994）, シグマ出版

23）成澤郁夫：プラスチックの破壊勒性, p. 53 (1993), シグマ出版

24) Osswald, T. A. and Menges, H.G/L. 武田邦彦（監 修) : エンジニアのためのプラスチック材料工学, p.325 (1997)，シグマ出版

25) Coats, A. W. and Redfern, J. P. : Nature, 201, 68(1964)

26) Freeman, E. S and Carroll, B. : J. Phys. Chem., 62, 394 (1958)

27）大塚良平；日本熱测定学会(編)：熱分析の基礎と応 用, 55 (1984), 科学技術社

28）増田芳雄 : 日本熱測定学会第 28 回熱測定講習会テキ スト, p.65 (1994)

29) Ozawa, T. : Bull. Chem. Soc. Jpn, 38, 881 (1965) 